\section{THE CHOLERA IN RUSSIA.}

To the Editor of THE LANCET.

SIR,-I now again beg to enclose the following extracts taken from the Journal of St. Petersburg, which, together with the bulletin printed in your previous issue (February 24th, 1872) will further illustrate, complete, and bring up to the latest date, the history and "spring outbreak" of cholera at Revel. The Russian time is always used in the official bulletin :-

From the Journal de St. Petersburg, January 27th, 1872 (English time).

"On mande de Rével que le port de cette ville est entièrement libre de glaces. Les bateaux à vapeur qui font la traversée de Rével à Hull ont repris leur service."

February 26th, 1872 (English time).

"On mande de Rével au Messager Officiel, sous la date du 5 Février, que la glace qui couvre le port de cette ville depuis le 29 Janvier s'est consolidée par l'effet des grands froids. La navigation est fermée."

From the Journal de St. Petersburg, February 29th, 1872 (English time)

"On mande de Rével, sous la date du 11 Férrier, que le choléra a complètement cessé dans cette ville, ou on sait qu'après $\mathrm{y}$ avoir sévi une première fois du 3 Octobre au 23 Novembre de l'aunée dernière, il avait fait une nouvelle apparition le 24: Décembre. Depuis cette date jusqu'à celle du 10 Février le nombre des cas a été de 145 , dont 86 suivis de décès. Lors de la première apparition de l'epidémie il n'y avait eu que 86 cas avec 54 décès.-Nordische Zeitung."

From the published statistics of cholera in Russia in 1871 , it was seen that the disease, besides exhibiting itself in virulent activity in the "spring outbreak" at St. Petersburg, flooded extensively the Governments to the north, south, as well as the south-west Gulf of Finland districts, commencing in all these in the spring months, and continuing till late in the year. Throughout these the "epidemic force" was only of third degree as to strength and diffusion and virulence of the epidemic, as compared with many of the less-favoured central and southern provinces of European Russia. It will therefore be a point of considerable interest and importance to epidemiologists to watch its history and further spread through the Russian and Prussian Baltic provinces during the present year 1872. I remain, Sir, yours obediently,

March, 1872 Wirliam D. MichesL.

\section{POOR-LAW MEDICAL RELIEF.}

To the Editor of THE LaNCET.

Sir,-A full report of the proceedings at the conference on Poor-law Medical Relief on the 5th, and at the deputation to Mr. Stansfeld on the 13th ult., having been forwarded to our members, during the last few days I have received from all parts of the country a large number of letters, in which the writers express their objection to the proposition of the Royal Sanitary Commission, which would constitute them (if adopted) the sole medical officers of health of their respective districts.

The enclosed copy of a resolution adopted at a meeting of the medical officers of the Cardiff Union places the matter in so clear a iight that I believe you would be doing us a service if you find space for it in your columns.

I am, Sir, yours obediently,

Dean-street, March 5th, 1872.

Jos. Rogers.

At a meeting of the medical officers of the Cardiff Union, held on the 27 th of February, it was unanimously agreed that-." We are most strongly of opinion that the recommendation of the Sanitary Commission, that district Poorlaw medical officers be sole sanitary officers, would be impracticable, as private practice would seriously interfere with the necessary independence. We believe the greatest efficiency would be obtained by charging them with the duty of reporting to a superior officer, independent of practice, who might preside over a wide area, and accept the responsibility of taking action for the removal of reported nuisances. Further, if this higher office were made open to the deputy officers who might prove their fitness for it, we think it would be a valuable stimulus to the thorough discharge of the duties of the subordinate post."-Signed, John Lewellyn, Richard Lougher, Alf. Sheen, M.D., James Milward, Edward Bates, F. W. Granger, Jno. Evans, David Edgar Jones.

\section{HOUSE OF COMMONS.}

FEB. 29 TH.

Mr. Gladstone, in reply to Sir J. Trelawney, stated that he did not see any probability of the Contagious Diseases Acts Bill being brought on for a second reading on the 21st of March, but notice of the day would be given.

\section{MARCH 6TH.}

Mr. Charlex moved the second reading of his Bill for the Better Protection of Infant Life, which last year was considered and remodeled by a Select Committee. The Bill provides that persons who take children to nurse for more than one day must be furnished with a certificate from a medical practitioner, a magistrate, or a minister of religion, which certificate may be cancelled on proof of neglect. A register of infants is to be kept in each house, and when a death occurs it must be notified to the coroner. The extreme penalty to be imposed is six months' imprisonment.

Mr. Walpole, in criticising its provisions, thought that compulsory registration of births would give greater facilities for tracing children, which drew from Mr. Bruce the information that the President of the Local Government Board is about to introduce a Bill for the Compulsory Re. gistration of Births. Mr. Hurst, Mr. Kinnaird, and Mr. Dalrymple, while supporting the principle of the Bill, thought it was not strict enough. Mr. Henley and Mr. Winterbotham, while fully acknowledging the good intentions of the promoters of the measure, did not expect great beneficial results from it.

The Bill was then read a second time.

Mr. Muntz, in moving the second reading of his Bill for Preventing the Adulteration of Food and Drugs, intimated that as Mr. Stansfeld's Public Health Bill would make it unnecessary, he should not proceed further with his own Bill if the Government measure were carried.

The Bill was then read a second time pro forma

\section{2ylteiral a defors.}

Apothecaries' Hald. - The following gentlemen passed their examination in the Science and Practice of Medicine, and received certificates to practise, on Feb. 29th:Atkinson, John Charles, Kew, Surrey. Collier, Nicholas Constantine, Turnham-green. Eady, George John, Chertsey, Surrey. Fendiek, Thomas Rowing, Mylne-street. Scott, Hubert Payne, Tiverton, Devon.

On the same day the following gentlemen passed their First Professional Examination :-

William Bull, Dublin; Frederick Cheesman Clark, St. Burtholomew' Hospital; Campbell William Pridmore, Westminster Hospital.

Indian Medical Service. - The following is the list of candidates for this Service who were successful at the competitive examination held at Burlington House on the 12th of February :-

Crombie, A

Murphy, W. R.

Joubert, C. H.

Russell, E. G.

Rranen, W. A. D.

Hall, G. C.

Hall, G. C.

Watson, $G$.

Gopal Chunder Roy

Reid, A. S.

McNally, C. J

Duke, $J$

Lang, J. A. T.

Russick Tall Du

S Butler, W. J.

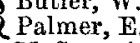

MeConaghey,

Wilson, J.
Marks
1885
1870
1870
1810
1795
1775
1730
1730
1690
1635
1665
1640
1615
1605
1600
1600
1550
1565
1530
1520 